\title{
PENGARUH MOTIVASI, MARKETING MIX DAN KONSEP DIRI TERHADAP KEPUTUSAN PEMBELIAN RUMAH BARU DI PERUMAHAN BUKIT CIMANGGU CITY BOGOR
}

\author{
THE INFLUENCE OF MOTIVATION, MARKETING MIX AND SELF CONCEPT OF NEW HOUSE \\ PURCHASE DECISION IN BUKIT CIMANGGU CITY BOGOR
}

\author{
Aditya Primarianto*), Lilik Noor Yuliati **), dan M. Joko Affandi***) \\ *) PT. ASDP Indonesia Ferry (Persero) \\ J1. Jend Achmad Yani Kav. 52A, Jakarta 10510 \\ ${ }^{* *}$ Departemen Ilmu Keluarga dan Konsumen, Fakultas Ekologi Manusia, Institut Pertanian Bogor \\ Gedung GMSK Lantai 2, Kampus IPB Dramaga Bogor 16680 \\ ***) Sekolah Tinggi Manajemen PPM \\ Jl. Menteng Raya No.9-19, Jakarta 10340
}

\begin{abstract}
The purpose of this study to determine the influence of motivation, marketing mix and self-concept of the decision to purchase a new house in Bukit Cimanggu City (BCC) housing Bogor City. This research was conducted by descriptive approach. The result of research analysis shows that motivation variable significantly influence consumer in decision of new house purchase in BCC, this is indicated from $t$-count value obtained $>1.96$. The most influence in the motivation factors to decide to buy a new house, is the purpose of consumers to meet the basic needs of residence, this is indicated by the value of loading factor of 1.00 larger than other indicators. Marketing Mix variables significantly influence consumers in new house purchase decisions in BCC, this is indicated from the t-count value obtained $>1.96$. The most influencing factor is product of BCC has an advantage in terms of house type, this is indicated by the value of loading factor of 0.79 is greater than other indicators. Self Concept Variables do not influence significantly to consumers in decision of new house purchase in BCC, this is indicated from $t$-count value obtained $<1.96$. The most influencing factor of self-concept in new house purchase decision is one's desire about how consumers perceive themselves to affect the products they buy and use it, this is indicated by the value of loading factor fix variabel is greater than other indicators. Purchasing decision has the most influence indicator that is finance, it is indicated by value of Loading Factor 0.78 bigger than other indicator. In this case the consumer in making the purchase decision is influenced by the financial condition.
\end{abstract}

Keywords: marketing mix, motivation, purchasing decision, self-concept

\begin{abstract}
Abstrak: Tujuan penelitian ini mengetahui pengaruh motivasi, bauran pemasaran dan konsep diri terhadap keputusan pembelian rumah baru di perumahan Bukit Cimanggu City (BCC) Kota Bogor. Penelitian ini dilakukan dengan pendekatan deskriptif. Hasil analisis penelitian menunjukkan bahwa variabel motivasi berpengaruh signifikan terhadap konsumen dalam keputusan pembelian rumah baru di BCC, ini ditunjukkan dari nilai t-hitung yang diperoleh $>1,96$. Pengaruh yang paling dalam faktor motivasi untuk memutuskan membeli rumah baru, adalah tujuan konsumen untuk memenuhi kebutuhan dasar tempat tinggal, hal ini ditunjukkan oleh nilai loading factor 1,00 lebih besar dari indikator lainnya. Variabel Marketing Mix berpengaruh signifikan terhadap konsumen dalam keputusan pembelian rumah baru di BCC, ini ditunjukkan dari nilai t-hitung yang diperoleh> 1,96. Faktor yang paling berpengaruh adalah produk BCC memiliki keuntungan dalam hal tipe rumah, ini ditunjukkan oleh nilai loading factor 0,79 lebih besar dari indikator lainnya. Variabel Konsep Diri tidak berpengaruh signifikan terhadap konsumen dalam keputusan pembelian rumah baru di BCC, ini ditunjukkan dari nilai t-hitung yang diperoleh $<1,96$. Faktor yang paling memengaruhi konsep diri dalam keputusan pembelian rumah baru adalah keinginan seseorang tentang bagaimana konsumen memandang dirinya untuk memengaruhi produk yang mereka beli dan gunakan, ini ditunjukkan oleh nilai variabel pembebanan faktor pemuatan lebih besar dari indikator lainnya. Keputusan pembelian memiliki pengaruh paling besar yaitu indikator keuangan, hal ini ditunjukkan oleh nilai loading factor 0,78 lebih besar dari indikator lainnya. Dalam hal ini konsumen dalam membuat keputusan pembelian dipengaruhi oleh kondisi keuangan.
\end{abstract}

Kata kunci: bauran pemasaran, motivasi, keputusan pembelian, konsep diri

\footnotetext{
${ }^{1}$ Alamat Korespondensi:

Email: primarianto@yahoo.com
} 


\section{PENDAHULUAN}

Rumah tak cukup hanya untuk berteduh namun juga harus bisa menjadi tempat tinggal yang layak (Prihandoyo et al. 2015). Seiring dengan gaya hidup masyarakat modern yang dinamis lebih cenderung membutuhkan rumah dengan berbagai fasilitas seperti keamanan, tempat ibadah, taman bermain didalam satu kawasan dengan sistem satu pintu akses keluar masuk atau disebut juga cluster (Sutianingsih, 2010). Dalam mencapai keberhasilan bisnis property, tentu perhatian para developer tidak lepas dari aspek konsumen karena pada dasarnya keberhasilan pemasaran produk, dalam hal ini perumahan sangat tergantung dari penerimaan konsumen terhadap produk tersebut (Rustandi, 2012).

Menurut perhitungan data area analytics dari website Urban Indo, sejak Bulan Oktober 2012 hingga Februari 2013 pemasaran properti untuk daerah Bogor selalu mengalami peningkatan setiap bulannya, di akhir bulan April 2013 total properti yang dipasarkan mencapai 3.623 properti. Dari total 3.623 properti tersebut terdiri dari: rumah 2.669 unit, tanah 717 unit, Vila 80 unit dan sisanya ruko, kost, apartemen dan komersial. Tipe properti yang paling diminati adalah rumah sebesar $75,66 \%$ disusul dengan Villa $9,24 \%$, tanah $9,01 \%$, ruko $2,05 \%$, kost $1,9 \%$, apartemen $1,16 \%$ dan komersial $0,37 \%$. Rumah merupakan properti yang paling diminati di Kota Bogor. Hal ini membuat industri properti melakukan investasinya di Kota Bogor.

Pengambilan keputusan konsumen adalah aspek penting bagi pemasar industri properti. Keputusan konsumen terkait erat dengan informasi yang dimiliki konsumen dan berbagai faktor yang dipengaruhi oleh pengetahuan konsumen tentang produk yang akan dibelinya (Sumarwan, 2011). Prihandoyo et al. (2015) menyebutkan keputusan konsumen dalam membeli rumah menggunakan indikator seperti kemampuan finansial, pengetahuan, evaluasi dan alternatif pilihan. Hal Ini didukung oleh penelitian yang dilakukan oleh Coolen dan Hoestra (2001) bahwa keputusan konsumen dalam memilih perumahan di pengaruhi oleh dua hal yaitu motivasi dan tujuan hidup, proses keputusan pembeliannya, yaitu identifikasi tujuan, motivasi, dan nilai yang diinginkan masing-masing konsumen, untuk dievaluasi lalu menentukan pilihan.

Penelitian oleh Tanata (2013) menyebutkan bahwa motivasi dalam pembelian memberikan pengaruh yang signifikan terhadap keputusan pembelian rumah.
Indikator yang digunakan sebagai variabel penelitian, yaitu kebutuhan dasar, untuk aktualisasi diri, pencitraan dan investasi. Dalam memenuhi kebutuhan konsumen dan dapat bersaing dengan kompetitor yang ada, para pengembang (developer) perlu memiliki strategi pemasaran yang tepat dan salah satu cara yang dapat ditempuh dengan memperhatikan perilaku konsumen. Begitu pentingnya perilaku konsumen, dapat menjadi bahan pertimbangan bagi para pengembang dalam melihat situasi pasar.

Strategi yang dilakukan salah satunya dengan melakukan strategi marketing mix yang dalam proses menyusunnya developer mempertimbangkan beberapa aspek seperti product yang menarik dan sesuai kebutuhan. Berdasarkan penelitian yang ditulis oleh Hausman (2000) hasilnya menunjukkan produk yang ditawarkan menjadi motif konsumen untuk melakukan pembelian. Place yang mudah diakses dan dekat dengan transportasi masal, dan price dengan membuat harga yang menarik dan terjangkau, serta promosi yang tepat agar dapat menarik minat dan menimbulkan suatu kebutuhan untuk membeli rumah (Sulistya dan Suharno, 2008).

Hendrawaty dan Pribadi (2015) melaporkan bahwa letak lokasi yang strategis, akses yang baik dan fasilitas umum yang memadai seperti tempat ibadah, sekolah, pusat perbelanjaan dan rumah sakit merupakan hal yang diperlukan oleh suatu perumahan, sehingga konsumen tertarik untuk membeli rumah di perumahan tersebut. Hasil dari penelitian Manivannan dan Somasundaram (2014) menjelaskan bahwa faktor fasilitas dasar seperti listrik, air, saluran pembuangan, area parkir memengaruhi keputusan pembelian perumahan. Berbagai variabel rumah seperti produk, fasilitas, citra pengembang, metode pembayaran dan faktor lainnya yang disediakan bisa dijadikan acuan untuk bisa menilai persepsi yang diinginkan oleh konsumen dan dijadikan penilaian apakah rumah-rumah baru tersebut dibeli disesuaikan dengan konsep diri seseorang karena konsep diri merupakan perasaan terhadap diri, gambaran deskriptif dan evaluatif mengenai kemampuan dan sifat seseorang (Xue, 2005).

Konsep diri dalam penelitian Fadli et al. (2013) mengemukakan bahwa terdapat hubungan yang positif signifikan dan kuat antara variabel konsep diri terhadap keputusan pembelian. Menurut Thomas (2013) konsep diri aktual, konsep diri ideal, konsep diri sosial aktual dan konsep diri sosial ideal semuanya memiliki 
hubungan yang positif dalam keputusan pembelian properti perumahan.

Dari gambaran tersebut serta didukung oleh penelitianpenelitian sebelumnya menunjukkan bahwa pembelian rumah baru masih menjadi pilihan utama bagi konsumen. Untuk itu dalam penelitian ini konsep pemasaran dari marketing mix akan dikombinasikan dengan konsep motivasi dan konsep diri terhadap keputusan pembelian rumah baru.

PT. Perdana Gapuraprima, Tbk (GPRA) telah membangun beberapa proyek besar salah satunya adalah Bukit Cimanggu City. Bukit Cimanggu City (BCC) perumahan berlokasi di Bogor, Jawa Barat, dengan luas 145 hektar dengan yang diakuisisi seluas 135 hektar dan telah terjual 121,2 hektar. Berdasarkan data internal rekapitulasi penjualan tahun 2015 bahwa target penjualan sebesar Rp253.061.595.100 sedangkan pencapaianpenjualanbersihsebesarRp185.875.592.100 (77\%). Untuk tahun 2016 target penjualan sebesar Rp234.086.807.000, pencapaian penjualan bersih Rp175.984.979.000 (73\%). Dapat dilihat bahwa terdapat penurunan\%tase penjualan sebesar $4 \%$. Hal ini juga dijelaskan oleh situs Indonesia Property Watch bahwa riset yang dilakukan terhadap proyekproyek perumahan wilayah studi Jabodebek-Banten, diperlihatkan bahwa nilai penjualan di triwulan I/2016 mengalami penurunan $23,1 \%$ dibandingkan triwulan sebelumnya $55,75 \%$. Demikian pula pada Desember 2016 sampai Januari 2017 banyak masyarakat yang menggunakannya untuk liburan, sehingga properti belum menjadi isu penting dalam pasar investor.

Dari data yang disebutkan dapat dilihat adanya penurunan jumlah penjualan di perumahan BCC dari tahun 2015 ke tahun 2016. Pemahaman yang mendalam mengenai konsumen akan memungkinkan pemasar dapat memengaruhi motivasi konsumen sehingga memutuskan untuk membeli produk yang di tawarkan (Rahmanie, 2010). Selain motivasi juga bisa dilihat dari aspek-aspek kepribadian individual yang merupakan ekspresi dari diri mereka yang disebut sebagai konsep diri (Ferrinadewi, 2008).

Pada penelitian ini dilihat segmen konsumen yang memiliki dan tinggal dirumah tersebut dilihat dari pengaruh motivasi, konsep diri dan strategi pemasaran marketing mix terhadap keputusan pembelian rumah baru di perumahan BCC. Berdasarkan latar belakang yang telah diuraikan maka tujuan penelitian ini adalah menganalisis faktor motivasi, marketing mix dan konsep diri yang berpengaruh terhadap keputusan pembelian rumah baru.

Penelitian ini hanya berfokus pada faktor-faktor motivasi, marketing mix dan konsep diri untuk mengetahui pengaruhnya terhadap keputusan pembelian rumah baru. Penelitian ini difokuskan pada pemilik rumah dan tinggal di Perumahan $\mathrm{BCC}$, tidak termasuk pemilik yang tidak tinggal di rumah tersebut.

\section{METODE PENELITIAN}

Penelitian dilakukan di perumahan Bukit Cimanggu City (BCC) yang berlokasi di Kota Bogor. Waktu pengambilan data dilakukan pada bulan April 2017 sampai dengan Juni 2017.

Metode penentuan sampel yang digunakan adalah non probability sampling, yaitu sampel yang dipilih berdasarkan pertimbangan-pertimbangan tertentu. Sampel pada penelitian ini adalah konsumen yang membeli rumah di perumahan $\mathrm{BCC}$ dan tinggal dirumah tersebut. Teknik pengambilan sampel dilakukan dengan metode convenience sampling. Pengambilan ukuran sampel dilakukan dengan menggunakan rule of thum dari Structural Equation Modeling (SEM). Menurut Hair et al. (2006) jumlah sampel yang dibutuhkan untuk setiap estimated parameter variabel eksogen dan endogen adalah lima hingga sepuluh observasi. Jumlah variabel indikator yang menyusun model SEM pada penelitian ini sebanyak (35) variabel indikator, maka batasan jumlah respondennya adalah $(35 \times 5=175)$ responden sampai dengan $(35 \times 10=350)$ responden. Untuk penelitian ini digunakan 175 responden.

Pengumpulan data dilakukan melalui self administered questionnaire, yaitu teknik pengambilan data dengan menyerahkan atau mengirimkan daftar pertanyaan untuk diisi sendiri oleh responden. Menurut Sumarwan (2011) kuesioner merupakan serangkaian pertanyaan yang diberikan kepada responden dimana responden diminta memberikan jawaban atas pertanyaan tersebut. Teknik penskalaan yang digunakan adalah skala Likert yang menggunakan skala $1-5$. Teknik pengolahan dan analisis data menggunakan SEM yang diolah dengan menggunakan Software Lisrel versi 8,7. 
Pendekatan penelitian yang digunakan dalam penelitian ini adalah metode penelitian deskriptif kuantitatif. Menurut Hadari (2003) metode deskriptif yaitu metode-metode penelitian yang memusatkan perhatian pada masalah-masalah atau fenomena yang bersifat aktual pada saat penelitian dilakukan, kemudian menggambarkan fakta-fakta tentang masalah yang diselidiki sebagaimana adanya diiringi dengan interprestasi yang rasional dan akurat. Penelitian ini memiliki tiga variabel eksogen, yakni faktor motivasi, faktor marketing mix, dan faktor konsep diri (Tabel 1). Variabel endogen terdiri dari faktor keputusan pembelian. Hipotesis dalam penelitian ini yakni sebagai berikut:

H1 : Motivasi mempunyai pengaruh terhadap keputusan pembelian rumah baru

H2 : Marketing Mix mempunyai pengaruh terhadap keputusan pembelian rumah baru

H3 : Konsep Diri mempunyai pengaruh terhadap keputusan pembelian rumah baru

\section{HASIL}

\section{Karakteristik Responden}

Dari hasil screening awal kuesioner jenis kelamin laki-laki memiliki proporsi yang mendominasi dalam menentukan keputusan pembelian perumahan BCC, yaitu dari seluruh responden 175 orang sebesar $67 \%$ berjenis kelamin laki-laki. Hal ini menunjukkan bahwa laki-laki memiliki pengaruh terhadap pengambilan keputusan pembelian. Usia respoden yang paling dominan adalah pada rentang usia 25-35 tahun, yaitu $50 \%$ dari jumlah responden. Jenjang pendidikan responden didominasi oleh lulusan Sarjana (S1) yaitu dengan $\%$ tase sebesar $61 \%$ dari total responden konsumen. Karakteristik responden selengkapnya pada Tabel 2.

Berdasarkan status responden, $89 \%$ responden berstatus menikah. Pendapatan tertinggi responden terdapat pada rentang Rp10.000.001 - Rp15.000.000 (30\%). Pada profil pekerjaan responden yang menentukan keputusan pembelian rumah didominasi pegawai swasta dengan persentase sebesar $53 \%$ dari total responden. Sementara dari hasil penelitian penghuni rumah tersebut memiliki pekerjaan di daerah Jakarta 44\%.

\section{Uji Validitas}

Pengujian validitas dilakukan untuk menguji alat ukur atau kuesioner yang digunakan valid atau tidak valid dengan menggunakan korelasi product moment. Pengambilan keputusan valid atau tidaknya atribut berdasarkan nilai $r$ hitung dibandingkan dengan nilai $\mathrm{r}$ tabel atau nilai probabilitas ( $\mathrm{p}$-value). Atribut dinyatakan valid bila koefisien korelasi (nilai r-hitung) $>$ r-tabel atau nilai p-value $<0,05$. Adapun r-tabel untuk $n=20$ adalah 0,444. Dengan demikian seluruh r-hitung (koefisien korelasi) yang diperoleh dari hasil pengolahan data penelitian ini lebih dari r-tabel. Hasil uji validitas ditampilkan pada Tabel 3 .

Hasil analisis menunjukkan bahwa pembentuk konstruk variabel keputusan pembelian rumah pada konsumen yang sudah membeli dinyatakan valid karena rataan corrected-total correction menghasilkan nilai lebih besar dari 0,444, jadi dapat disimpulkan bahwa semua pernyataan dalam tahap uji coba adalah valid, responden dapat mengerti maksud dari setiap pernyataan yang diajukan oleh peneliti dan kuesioner tersebut layak untuk diberikan kepada seluruh responden (Ghozali, 2008).

Tabel 1. Variabel operasional penelitian

\begin{tabular}{lllll}
\hline \multirow{2}{*}{ Variabel laten } & \multicolumn{3}{c}{ Eksogen } & Endogen \\
\cline { 2 - 5 } & \multicolumn{1}{c}{ Motivasi } & Marketing mix & Konsep diri & $\begin{array}{c}\text { Keputusan pembelian } \\
\text { rumah baru }\end{array}$ \\
\hline Dimensi variabel & Tujuan & Product (X3) & Konsep diri Aktual (X7) & Keuangan (Y1) \\
laten & Generik (X1) & Price (X4) & Konsep diri Ideal (X8) & Pengetahuan (Y2) \\
& Tujuan-Produk & Promotion (X5) & Konsep diri pribadi (X9) & Evaluasi (Y3) \\
& Khusus & Place (X6) & Konsep diri Sosial (X10) & Alternatif pilihan (Y4) \\
& (X2) & & & \\
\hline
\end{tabular}


Tabel 2. Karakteristik responden

\begin{tabular}{|c|c|c|c|}
\hline Karakteristik & Kategori & Jumlah & Persen \\
\hline \multirow{3}{*}{$\begin{array}{l}\text { Jenis } \\
\text { Kelamin }\end{array}$} & Pria & 117 & $67 \%$ \\
\hline & Wanita & 58 & $33 \%$ \\
\hline & Jumlah & 175 & $100 \%$ \\
\hline \multirow[t]{6}{*}{ Umur } & $<25$ tahun & 13 & $7 \%$ \\
\hline & 25-35 Tahun & 88 & $50 \%$ \\
\hline & 36-45 Tahun & 53 & $30 \%$ \\
\hline & 46-55 Tahun & 16 & $9 \%$ \\
\hline & $>55$ Tahun & 5 & $3 \%$ \\
\hline & Jumlah & 175 & $100 \%$ \\
\hline \multirow[t]{8}{*}{ Pendidikan } & $\mathrm{SD}$ & & $0 \%$ \\
\hline & SMP & 1 & $1 \%$ \\
\hline & SMA & 18 & $10 \%$ \\
\hline & Diploma/Akademi & 31 & $18 \%$ \\
\hline & $\mathrm{S} 1$ & 107 & $61 \%$ \\
\hline & $\mathrm{S} 2$ & 17 & $10 \%$ \\
\hline & $\mathrm{S} 3$ & 1 & $1 \%$ \\
\hline & Jumlah & 175 & $100 \%$ \\
\hline \multirow[t]{3}{*}{ Status } & Belum Menikah & 20 & $11 \%$ \\
\hline & Sudah Menikah & 155 & $89 \%$ \\
\hline & Jumlah & 175 & $100 \%$ \\
\hline \multirow[t]{7}{*}{ Pendapatan } & $<\operatorname{Rp} 5.000 .000$ & 16 & $9 \%$ \\
\hline & $\begin{array}{l}5.000 .001- \\
10.000 .000\end{array}$ & 51 & $29 \%$ \\
\hline & $\begin{array}{l}10.000 .001- \\
15.000 .000\end{array}$ & 52 & $30 \%$ \\
\hline & $\begin{array}{l}15.000 .001- \\
20.000 .000\end{array}$ & 27 & $15 \%$ \\
\hline & $\begin{array}{l}20.000 .001- \\
25.000 .000\end{array}$ & 12 & $7 \%$ \\
\hline & $>25.000 .000$ & 17 & $10 \%$ \\
\hline & Jumlah & 175 & $100 \%$ \\
\hline \multirow[t]{7}{*}{ Pekerjaan } & Pelajar/Mahasiswa & 6 & $3 \%$ \\
\hline & Pegawai Negeri & 21 & $12 \%$ \\
\hline & Pegawai Swasta & 93 & $53 \%$ \\
\hline & Wiraswasta & 34 & $19 \%$ \\
\hline & Ibu Rumah Tangga & 20 & $11 \%$ \\
\hline & Lainnya & 1 & $1 \%$ \\
\hline & Jumlah & 175 & $100 \%$ \\
\hline \multirow{7}{*}{$\begin{array}{l}\text { Daerah } \\
\text { Bekerja }\end{array}$} & Kab.Bogor & 55 & $31 \%$ \\
\hline & Jakarta & 77 & $44 \%$ \\
\hline & Tangerang & 3 & $2 \%$ \\
\hline & Depok & 9 & $5 \%$ \\
\hline & Bekasi & 3 & $2 \%$ \\
\hline & Lainnya & 28 & $16 \%$ \\
\hline & Jumlah & 175 & $100 \%$ \\
\hline
\end{tabular}

Tabel 3. Tabel uji validitas

\begin{tabular}{|c|c|c|c|c|}
\hline Variabel & Indikator & $\begin{array}{c}\text { Koefisien } \\
\text { korelasi }\end{array}$ & r-tabel & Keterangan \\
\hline $\begin{array}{l}\text { Tujuan } \\
\text { Generik (X1) }\end{array}$ & $\mathrm{X} 11$ & 1,000 & 0,444 & Valid \\
\hline \multirow{4}{*}{$\begin{array}{l}\text { Tujuan } \\
\text { Produk } \\
\text { Khusus } \\
\text { (X2) }\end{array}$} & $\mathrm{X} 21$ & 0,895 & 0,444 & Valid \\
\hline & X22 & 0,867 & 0,444 & Valid \\
\hline & $\mathrm{X} 23$ & 0,890 & 0,444 & Valid \\
\hline & $\mathrm{X} 24$ & 0,789 & 0,444 & Valid \\
\hline \multirow[t]{5}{*}{ Product (X3) } & X31 & 0,609 & 0,444 & Valid \\
\hline & $\mathrm{X} 32$ & 0,799 & 0,444 & Valid \\
\hline & X33 & 0,681 & 0,444 & Valid \\
\hline & X34 & 0,684 & 0,444 & Valid \\
\hline & X35 & 0,826 & 0,444 & Valid \\
\hline \multirow[t]{4}{*}{ Price (X4) } & X41 & 0,889 & 0,444 & Valid \\
\hline & $\mathrm{X} 42$ & 0,837 & 0,444 & Valid \\
\hline & $\mathrm{X} 43$ & 0,894 & 0,444 & Valid \\
\hline & X44 & 0,868 & 0,444 & Valid \\
\hline \multirow{3}{*}{$\begin{array}{l}\text { Promotion } \\
\text { (X5) }\end{array}$} & X51 & 0,854 & 0,444 & Valid \\
\hline & $\mathrm{X} 52$ & 0,894 & 0,444 & Valid \\
\hline & $\mathrm{X} 53$ & 0,748 & 0,444 & Valid \\
\hline \multirow[t]{7}{*}{ Place (X6) } & X61 & 0,741 & 0,444 & Valid \\
\hline & X62 & 0,763 & 0,444 & Valid \\
\hline & X63 & 0,796 & 0,444 & Valid \\
\hline & X64 & 0,794 & 0,444 & Valid \\
\hline & X65 & 0,837 & 0,444 & Valid \\
\hline & X66 & 0,862 & 0,444 & Valid \\
\hline & X67 & 0,784 & 0,444 & Valid \\
\hline \multirow{4}{*}{$\begin{array}{l}\text { Konsep Diri } \\
\text { Aktual (X7) }\end{array}$} & X71 & 0,898 & 0,444 & Valid \\
\hline & X72 & 0,854 & 0,444 & Valid \\
\hline & X73 & 0,935 & 0,444 & Valid \\
\hline & X74 & 0,876 & 0,444 & Valid \\
\hline \multirow{4}{*}{$\begin{array}{l}\text { Konsep Diri } \\
\text { Ideal (X8) }\end{array}$} & X81 & 0,947 & 0,444 & Valid \\
\hline & X82 & 0,937 & 0,444 & Valid \\
\hline & $\mathrm{X} 83$ & 0,740 & 0,444 & Valid \\
\hline & X84 & 0,954 & 0,444 & Valid \\
\hline \multirow{4}{*}{$\begin{array}{l}\text { Konsep Diri } \\
\text { Pribadi (X9) }\end{array}$} & X91 & 0,906 & 0,444 & Valid \\
\hline & X92 & 0,964 & 0,444 & Valid \\
\hline & X93 & 0,928 & 0,444 & Valid \\
\hline & X94 & 0,942 & 0,444 & Valid \\
\hline \multirow{4}{*}{$\begin{array}{l}\text { Konsep Diri } \\
\text { Sosial (X10) }\end{array}$} & X101 & 0,906 & 0,444 & Valid \\
\hline & X102 & 0,868 & 0,444 & Valid \\
\hline & X103 & 0,861 & 0,444 & Valid \\
\hline & X104 & 0,892 & 0,444 & Valid \\
\hline \multirow{4}{*}{$\begin{array}{l}\text { Keputusan } \\
\text { Pembelian } \\
\text { (Y) }\end{array}$} & Y1 & 0,756 & 0,444 & Valid \\
\hline & $\mathrm{Y} 2$ & 0,787 & 0,444 & Valid \\
\hline & Y3 & 0,962 & 0,444 & Valid \\
\hline & Y4 & 0,739 & 0,444 & Valid \\
\hline
\end{tabular}




\section{Uji Reliabilitas}

Uji reliabilitas yang akan digunakan dalam penelitian ini, adalah dengan menggunakan fasilitas SPSS, yakni dengan uji statistik Cronbach Alpha. Hasil pengujian reliabilitas terhadap seluruh indikator pada dimensidimensi yang digunakan dalam penelitian dapat diterima, demikian juga untuk keseluruhan tingkat pengukuran sesuai dengan yang dikemukakan oleh Ghozali (2006) menyatakan bahwa suatu konstruk atau variabel dinyatakan reliabel jika nilai cronbach alpha> 0,60 (Nunnally, 1990 dalam Ghozali, 2006). Hasil uji realibilitas ditampilkan pada Tabel 4.

Hasil pengujian reliabilitas terhadap seluruh pertanyaan yang terdiri dari 44 pertanyaan atas dimensi-dimensi pembentuknya menunjukkan sebagai suatu ukuran reliabel karena masing-masing memilikinilaireliabilitas lebih besar dari nilai std Alpha 0,6 sehingga pertanyaan kuesioner tersebut layak untuk digunakan.

\section{Hasil Pengujian Hipotesis}

Pengujian hipotesis digunakan untuk mengetahui apakah hipotesis didukung oleh data atau tidak, maka nilai statistik $t$ dibandingkan dengan nilai t tabel sebesar 1,96 (Ghozali, 2008). Apabila nilai t hitung $>1,96$, maka dapat disimpulkan bahwa hipotesis penelitian didukung oleh data (terbukti secara signifikan). Berdasarkan analisis statistik dengan menggunakan program LISREL, diperoleh hasil uji hipotesis yang merupakan uji pengaruh variabel eksogen, yaitu motivasi, Marketing Mix dan konsep diri terhadap variabel endogen keputusan pembelian. Hasil SEM dapat dijelaskan pada Tabel 5.

Tabel 4. Uji hasil realiabilitas

\begin{tabular}{lccc}
\hline Variabel & Cronbach's Alpha & N of Items & Keputusan \\
\hline Tujuan generik (X1) & 1,000 & 1 & Reliabel \\
Tujuan produk khusus (X2) & 0,940 & 4 & Reliabel \\
Product (X3) & 0,730 & 5 & Reliabel \\
Price (X4) & 0,875 & 4 & Reliabel \\
Promotion (X5) & 0,768 & 3 & Reliabel \\
Place (X6) & 0,894 & 7 & Reliabel \\
Konsep diri aktual (X7) & 0,912 & 4 & Reliabel \\
Konsep diri ideal (X8) & 0,921 & 4 & Reliabel \\
Konsep diri pribadi (X9) & 0,946 & 4 & Reliabel \\
Konsep diri sosial (X10) & 0,899 & 4 & Reliabel \\
Keputusan pembelian (Y) & 0,831 & 4 & Reliabel \\
\hline
\end{tabular}

Tabel 5. Kontribusi indikator variabel eksogen dan variabel endogen

\begin{tabular}{llccl}
\hline \multicolumn{1}{c}{ Variabel } & \multicolumn{1}{c}{ Indikator } & Loading faktor & t-hitung & Keterangan \\
\hline Motivasi & TG & 1,00 & 24,35 & Signifikan \\
& TPK & 1,00 & 19,03 & Signifikan \\
& Product & 0,93 & 21,19 & Signifikan \\
& Price & 0,74 & 20,97 & Signifikan \\
\multirow{5}{*}{ Konsep diring Mix } & Promotion & 0,68 & 20,63 & Signifikan \\
& Place & 0,56 & 18,16 & Signifikan \\
& KDA & 1,00 & 23,01 & Signifikan \\
& KDI & 0,95 & 22,13 & Signifikan \\
& KDP & 0,94 & 21,22 & Signifikan \\
Keputusan & KDS & 0,76 & 17,54 & Signifikan \\
pembelian & Keuangan & 0,78 & Fix Variabel & Signifikan \\
& Pengetahuan & 0,63 & 7,02 & Signifikan \\
& Evaluasi & 0,64 & 7,16 & Signifikan \\
& Alternatif Pilihan & 0,50 & 4,45 & Signifikan \\
\hline
\end{tabular}


Terlihat pada Tabel 5 bahwa variabel Motivasi yang terdiri atas indikator TG dan TPK masing-masing memiliki kontribusi loading factor sebesar 1,00. Indikator TG memiliki kontribusi yang lebih dominan dari indikator TPK terhadap Motivasi dari nilai t-hitung. Variabel marketing mix yang terdiri atas indikator product, price, promotion, dan place masing-masing memiliki kontribusi loading factor sebesar 0,93, 0,74, 0,68, dan 0,56. Indikator Product memiliki kontribusi yang lebih dominan dari indikator price, promotion dan place terhadap marketing mix. Variabel konsep diri yang terdiri atas Indikator KDA, KDI, KDP, dan KDS masingmasing memiliki kontribusi loading factor sebesar 1,00, 0,95, 0,94, dan 0,76. Indikator KDA memiliki kontribusi yang lebih dominan dari indikator KDI, KDP, dan KDS terhadap konsep diri.

Pengujian hipotesis untuk menguji pengaruh langsung motivasi, marketing mix dan konsep diri terhadap keputusan pembelian dapat dijelaskan pada Tabel 6. Hasil uji hipotesis menunjukkan bahwa pengaruh Motivasi terhadap keputusan pembelian sebesar 0,43 dengan t-hitung 13,38. Nilai t-hitung lebih besar dari t-tabel artinya pengaruh motivasi significant dan positif terhadap keputusan pembelian. Pengaruh marketing mix terhadap Keputusan pembelian sebesar 0,48 dengan t-hitung 10,10. Karena nilai t-hitung lebih besar dari t-tabel artinya pengaruh marketing mix significant dan positif terhadap Keputusan Pembelian. Pengaruh Konsep Diri terhadap Keputusan Pembelian sebesar $-0,03$ dengan t-hitung 0,55 . Karena nilai t-hitung lebih kecil dari t-tabel artinya pengaruh konsep diri tidak significant dan negatif terhadap keputusan pembelian.

\section{Hubungan antara Variabel Motivasi dengan Indikatornya}

Hasil estimasi model struktural (Tabel 5) dapat mengetahui indikator yang memberikan kontribusi terbesar. Efek langsung terbesar pada motivasi adalah dimensi variabel TG (tujuan generik) dengan $\mathrm{t}$-value 24,35, dengan variabel teramati X11 (kebutuhan dasar) dengan loading factor 1 . Hal ini berarti dimensi variabel TG dengan variabel teramati X11 memberikan kontribusi paling tinggi dalam bentuk hubungan yang positif dan signifikan dibandingkan TPK (tujuan produk khusus) dengan t-value 19,03.

Variabel laten eksogen motivasi diambil dari dua segmen yang terbentuk dari analisis faktor, dimana dimensi variabel X1 merupakan segmen tujuan generik, X2 segmen tujuan produk khusus. Masing-masing dimensi variabel diharapakan dapat mewakili dimensi yang lain yang terdapat pada setiap segmen. Pada hasil dapat dilihat bahwa segmen tujuan generik yang berpengaruh signifikan terhadap variabel laten eksogen motivasi. Hal ini berarti bahwa segmen TG akan meningkatkan nilai variabel laten eksogen motivasi, yang akan meningkatkan keputusan pembelian rumah di perumahan BCC.

\section{Hubungan antara Variabel Marketing Mix dengan indikatornya}

Hasil estimasi model struktural (Tabel 5) dapat mengetahui indikator yang memberikan kontribusi terbesar. Efek langsung terbesar pada marketing mix adalah dimensi variabel product dengan t-value 21.19, dengan variabel teramati X31 (bentuk rumah) dengan loading factor 0,79 . Hal ini berarti dimensi variabel product dengan variabel teramati X31 memberikan kontribusi paling tinggi dalam bentuk hubungan yang positif dan signifikan dibandingkan price, promotion dan place dengan t-value masing-masing 20,97, 20,63 dan 18,16 .

Variabel laten eksogen marketing mix diambil dari empat segmen yang terbentuk dari analisis faktor, dimana dimensi variabel X3 merupakan segmen product, X4 segmen price, X5 segmen promotion, dan X6 segmen place. Masing-masing dimensi variabel diharapakan dapat mewakili dimensi yang lain yang terdapat pada setiap segmen. Pada hasil dapat dilihat bahwa segmen product yang berpengaruh signifikan terhadap variabel laten eksogen marketing mix. Hal ini berarti bahwa segmen product akan meningkatkan nilai variabel laten eksogen marketing mix, yang akan meningkatkan keputusan pembelian rumah di perumahan BCC.

\section{Hubungan antara Variabel Konsep Diri dengan Indikatornya}

Hasil estimasi model struktural (Tabel 5) dapat mengetahui indikator yang memberikan kontribusi terbesar. Efek langsung terbesar pada konsep diri adalah dimensi variabel konsep diri aktual dengan t-value 23,01 dengan variabel teramati X71 (citra pribadi) dengan loading factor 1 . Hal ini berarti dimensi variabel konsep diri dengan variabel teramati X71 memberikan kontribusi paling tinggi dalam bentuk hubungan yang positif dan signifikan dibandingkan konsep diri ideal, konsep diri pribadi dan konsep diri sosial dengan t-value masing-masing 22,13; 21,11; dan 17,54. 
Variabel laten eksogen konsep diri diambil dari empat segmen yang terbentuk dari analisis faktor, dimana dimensi variabel $\mathrm{X} 7$ merupakan segmen konsep diri aktual, X8 segmen konsep diri ideal, X9 segmen konsep diri pribadi dan X10 segmen konsep diri sosial. Masingmasing dimensi variabel diharapakan dapat mewakili dimensi yang lain yang terdapat pada setiap segmen. Pada hasil dapat dilihat bahwa segmen konsep diri aktual yang berpengaruh signifikan terhadap variabel laten eksogen konsep diri.

\section{Implikasi Manajerial}

Implikasi manajerial yang diperoleh dari hasil penelitian ini dirangkum dalam bentuk segmentation, targeting, dan positioning (STP). Hal tersebut dapat digunakan oleh perusahaan sebagai bahan informasi dan pertimbangan dalam membuat strategi pemasaran produk perumahan BCC Bogor agar penjualan produk dapat meningkat sesuai dengan target perusahaan. Implikasi manajerial berdasarkan STP adalah sebagai berikut:

\section{Segmentation}

Segmentation produk perumahan BCC, yaitu kelompok dewasa yang sudah menikah karena pasangan yang sudah menikah melakukan pembelian rumah dengan tujuan untuk memenuhi kebutuhan dasar yaitu tempat tinggal dalam membangun keluarga. Hal tersebut dapat dijadikan bahan pertimbangan bagi perusahanan untuk memfokuskan pemasaran produk dengan menelusuri aktifitas dan perilaku konsumen. Salah satunya dengan melakukan pemasaran dalam bentuk promosi melalui pembuatan video tentang bentuk rumah BCC yang ideal, kemudian disebarkan melalui media sosial yang saat ini menjadi media yang paling banyak digunakan dan sangat cepat dalam penyebaran infomasi. Hal ini sesuai dengan hasil penelitian terdahulu oleh Marhadi et al. (2013) yang mengatakan bahwa variabel promosi (promotion) berpengaruh secara signifikan dan positif terhadap keputusan pembelian konsumen di perumahan PT. Asta Karya Pekanbaru.

\section{Targeting}

Target konsumen bagi perumahan BCC adalah konsumen dengan pendapatan antara Rp10.000.001 sampai dengan Rp15.000.000. Perusahaan dapat menerapkan harga premium bagi produk-produk limited edition. Discount harga ataupun cashback dapat diterapkan pada konsumen potensial untuk mendapatkan harga di bawah harga normal sehingga dapat memberikan keringanan dalam pengajuan Kredit Pemilikan Rumah (KPR) dan mengurangi biaya cicilan per bulan, proses negosiasi yang baik antara tenaga marketing dan konsumen untuk pemberian harga discount akan meningkatkan jumlah peminat perumahan sehingga akan mencapai target penjualan yang diinginkan. Hal ini sesuai dengan hasil penelitian terdahulu oleh Prihandoyo et al. (2015) dalam penelitiannya menunjukkan bahwa variabel harga (price) dan lokasi (place) dengan hasil secara parsial terbukti mempunyai pengaruh terhadap keputusan pembelian rumah.

\section{Positioning}

Perumahan BCC harus dapat menempatkan diri sebagai perumahan yang sesuai dengan keinginan konsumen menengah ke atas. Salah satu cara yang dapat dilakukan oleh developer adalah dengan cara memberikan informasi secara terus menerus tentang keunggulan perumahan BCC. Keunggulannya adalah memiliki lokasi strategis, dekat dengan rumah sakit yang hanya berjarak kurang dari $3 \mathrm{~km}$, sekolah negeri dan swasta, transportasi umum yang sangat dekat dan banyak seperti angkutan umum dalam kota, bis antar kota dan provinsi, ojek pangkalan maupun ojek online, stasiun commuter line Cilebut hanya berjarak $\pm 2 \mathrm{~km}$ serta akses jalan tol menuju tol Jagorawi dan tol lingkar luar Bogor yang menjadi keunggulan dari sisi lokasi. Selain itu BCC memiliki konsep perumahan cluster dengan dilengkapi dengan CCTV dan security 24 jam untuk keamanan dan fasilitas umum seperti taman bermain anak dan olahraga. Dengan informasi yang diberikan secara terus menerus tersebut akan menciptakan kesan bagi konsumen potensial bahwa perumahan BCC memiliki nilai lebih dari segi konsep dan lokasi yang strategis sehingga akan memicu motivasi dalam diri konsumen dalam melakukan pembelian rumah. Hal ini sesuai dengan hasil penelitian terdahulu oleh Manivannan dan Somasundaram (2014) menyatakan bahwa faktor produk dasar seperti listrik, air, saluran pembuangan, area parkir memengaruhi keputusan pembelian perumahan dan diikuti oleh faktor keuangan, layout, lokasi, tempat rekreasi, dan hiburan saat membeli rumah. 


\section{KESIMPULAN DAN SARAN}

\section{Kesimpulan}

Variabel laten eksogen Motivasi secara signifikan memengaruhi keputusan pembelian. Faktor yang paling memengaruhi motivasi dalam keputusan pembelian rumah baru yaitu memenuhi kebutuhan dasar yaitu sebagai tempat tinggal. Variabel laten eksogen Marketing Mix secara signifikan memengaruhi keputusan pembelian. Faktor yang paling memengaruhi marketing mix dalam keputusan pembelian rumah baru yaitu product dari BCC memiliki keunggulan dalam hal bentuk rumah. Variabel laten eksogen Konsep Diri tidak pengaruh secara signifikan terhadap keputusan pembelian. Faktor yang paling memengaruhi konsep diri dalam keputusan pembelian rumah baru yaitu pembeli rumah di BCC memandang dirinya akan memengaruhi produk yang dibeli dan digunakannya. Variabel laten endogen keputusan pembelian mempunyai indikator yang paling pengaruh yaitu dalam pengambilan keputusan pembelian rumah disesuaikan dengan kondisi keuangan.

\section{Saran}

Saran untuk penelitian selanjutnya antara lain: penelitian ini hanya mengambil contoh dari responden yang membeli dan tinggal di perumahan BCC dengan alat ukur variabel motivasi, marketing mix dan konsep diri. Untuk penelitian selanjutnya dapat memasukkan variabel-variabel lainnya terkait dengan keputusan pembelian seperti green product, gaya hidup, dan kebutuhan konsumen. Selanjutnya, berdasarkan hasil penelitian variabel konsep diri tidak berpengaruh secara signifikan terhadap keputusan pembelian rumah. Untuk penelitian selanjutnya dalam menggunakan variabel konsep diri dapat menambahkan indikator yang lain seperti situational self dengan variabel teramati pekerjaan dan keluarga (Fadli et al. 2013). Penelitian selanjutnya akan berkonsentrasi pada detail pilihan pelanggan. Jika penelitian ini hanya fokus pada rumah baru maka pada penelitian selanjutnya dapat ditambah opsi seperti apartemen, villa, dan bangunan komersial.

\section{DAFTAR PUSTAKA}

Coolen H, Hoestra J. 2001. Values as determinants of preferences for housing attributes. Journal of
Housing and Built Environment 16(3): 285-306. https://doi.org/10.1023/A:1012587323814.

Fadli UMD, Hasbullah R, Hadiyanto I. 2013. Pengaruh konsep diri terhadap keputusan pembelian mobil suzuki swift (studi kasus pada dealer restu mahkota karya karawang). Jurnal Manajemen 10(3): 1266-1277.

Ferrinadewi E. 2008. Merek dan psikologi konsumen. Jakarta: Graha Ilmu.

Ghozali I.2008. Model Persamaan Struktural Konsep dan Aplikasi dengan Program Amos 16.0. Semarang: Badan Penerbit UNDIP.

Hadari N. 2003. Metode Penelitian Bidang Sosial. Yogyakarta: UGM Press.

Hair J, Bill B, Bary JB, Rudolph AE, Rudolp LT. 2006. Multivariate Data Analysis. Ed ke-6. New Jersey: Pearson Prentice Hall.

Hendrawaty R, Pribadi NW. 2015. Analisis pengaruh bauran pemasaran terhadap keputusan konsumen dalam pembelian rumah di Perumahan Green Hills Regency Trenggalek. Jurnal Arthavidya 17(1):1-14.

Manivannan P, Somasundaram M. 2014. Purchase of residentials flats - factors influencing the decisions of buyers in selected cities in Tamil Nadu. International Research Journal of Business and Management 7(9): 67-73.

Prihandoyo C, Arrywibowo I, Awaliyah A. 2015. Analisis pengaruh harga, lokasi, bangunan dan lingkungan terhadap keputusan konsumen membeli rumah. Sustainable Competitive Advantage (SCA) 5(1): 1-17.

Rahmanie AT. 2010. Faktor psikologis, lingkungan dan bauran pemasaran yang memengaruhi pembelian sepeda motor studi pada konsumen sepeda motor bebek 4-tak merk suzuki dan honda di Kota Banjarmasin. Wacana 13(2) 301-313.

Rustandi M. 2012. Analisis preferensi dan marketing mix serta implikasinya terhadap pengembangan kawasan perumahan baru bogor nirwana residence [tesis]. Bogor: Manajemen dan Bisnis Institut Pertanian Bogor.

Sulistiya I, Suharno. 2008. Analisis dan penyusunan strategi pemasaran hypermarket. Bulletin Ekonomi Perikanan 8(2): 23-40.

Sumarwan U. 2011. Perilaku konsumen. Bogor: Ghalia Indonesia.

Sutianingsih. 2010. Keputusan konsumen dalam membeli perumahan. Riset Manajemen dan Akutansi 1(2): 97-111. 
Tanata F. 2013. Pengaruh persepsi dan motivasi konsumen terhadap keputusan pembelian (studi kasus perumahan poris paradise ekslusif tangerang). Jurnal Marketing Communication, Fakultas Ekonomi dan Komunikasi, Binus University.
Thomas M. 2013. Identity: its purpose and function within consumer residential property purchase decisions [theses]. New South Wales: Southern Cross University.

Xue F. 2005. Self-concept, consumption situation and advertising effectiveness. American Academy of Advertising. Conference. Proceedings 67. 